\title{
THE ROLE OF MEDIATING JOB SATISFACTION TO IMPROVE ORGANIZATIONAL JUSTICE AND TURNOVER INTENTIONS
}

\author{
Abdullah Rosyid Wicaksono ${ }^{1)}$, Shofia Amin ${ }^{2)}$, Agus Solihin ${ }^{3)}$ \\ ${ }^{1}$ Magister Management Program, Faculty of Economics and Business, Universitas Jambi \\ ${ }^{2 *}, 3$ Department of Management Faculty of Economics and Business, Universitas Jambi \\ Corresponding author: shofiaamin@unja.ac.id
}

\begin{abstract}
This study examines the relationship organizational justice and turnover intentions either directly or through job satisfaction as a mediating variable. Using a survey research design, questionnaires were distributed to 101 employees. For testing hypothesis, using PLS-SEM with the SmartPLS 3.0 software tool. The results indicated that the all hypotheses are accepted. It implies that organizational justice and turnover intension has a negative and significant relationship, but has a positive and significant relationship on Job Satisfaction. Meanwhile, Job Satisfaction has a negative and significant relationship on Turnover Intentions. So that, Job Satisfaction act as mediator variable between the relationship Organizational Justice and Turnover Intentions. To decrease turnover intentions, it could be done through increasing organizational justice and job satisfaction.
\end{abstract}

Keywords: Organizational justice, job satisfaction, turnover intention, mediating variable

\section{Introduction}

Employees significantly contribute to creating a competitive advantage for a company. Thus, a company needs to manage its human resources to be advanced in business competition. It is in line with Dessler (2011), who stated that a company's employees, including their knowledge, commitment, skills, and training, provide world-class companies' competitiveness. In maintaining employees' performances, there are several problems that employees might face, one of which is turnover intentions. According to Wong et al. (2015), when the level of employee turnover intentions increases, it will reduce the level of employee performance. Mobley (1977) also stated that the main predictors of voluntary turnover is turnover intention. Moreover, Sanderson (2003) mentioned that employees' turnover intentions would make a company spend recruitment and placement costs, education costs, and other employee adjustments.

In reducing employees' turnover intentions, companies need to pay attention to affecting factors; one of them is organizational justice. Grennberg \& Baron (2008) defined organizational justice as employees' perceptions of rights and fairness in organizational life. Every employee certainly has a different perception regarding the rights and what they get in organizations. Celik et al. (2016) explained there is a negative relationship between organizational justice and turnover intentions. Hence, it is clear that organizational justice is one of the factors of employees' turnover intentions.

Another factor that might reduce turnover intentions is job satisfaction. Robbins and Judge (2015); Suifan et al. (2017) mentioned the higher the level of employees' job satisfaction, the lower employees' turnover intentions. As an affecting factor on the turnover intentions, job satisfaction is related to and allegedly influenced by organizational justice. Previous studies such as Nadiri \& Tanova (2010); Arab \& Atan (2018), found that organizational justice relate to job satisfaction positively and significantly. These studies showed that a greater level of organizational justice would increase employees' job satisfaction.

However, there have been diverse literature about the three variables among researchers. Bayarcelik \& Findikli (2016) explain that job satisfaction intervenes between organizational justice and turnover intentions. It is also supported by Zagladi et al.'s (2015) study, which showed job satisfaction act as a mediator variable between organizational justice and turnover intentions. On the other hand, Hall \& Smith (2009) explained no significant relationship between organizational justice and turnover intentions. Based on the various result, it is necessary to seek whether job satisfaction mediates the relationship between organizational justice and turnover intentions.

This study investigates the extent to which organizational justice in a company affects job satisfaction and employee turnover intentions. The study was undertaken in PT. Tiga Serangkai Pustaka Mandiri. It is a company engaged in printing and publishing and has a distribution reach in almost all parts of Indonesia. PT. Tiga Serangkai Pustaka Mandiri has 34 branches throughout Indonesia, and eight of them are placed in Sumatra. Based on the initial study, the authors indicated turnover intentions among the employees of PT. Tiga Serangkai Mandiri branch office. The initial study showed that turnover intentions had become a problem for the company, especially in the Sumatra regions. Therefore, the company needs to formulate and determine effective strategies to reduce employee turnover intentions to maintain and improve employee performance and keep employees persisting in the company. 


\section{Organizational Justice (OJ) and Turnover Intention (TI)}

There are several factors that influence turnover intentions. Shields and Ward (2001) proposed the influencing factors: low salary, low benefits, inflexible working hours, and low career advancement opportunities. As one of a components of organizational justice, distributive justice is employees' perception of fairness. Employees will evaluate whether the results they get from an organization are worthy of their efforts (Niehoff \& Moorman, 1993; Colquit, 2001; Robbins \& Judge, 2015). A dimension of organizational justice, distributive justice, is found to be influential for turnover intentions. These theories assumed that OJ has a negative relationship with TI. That is, if there is an increase in organizational justice, it will reduce employee turnover intentions. Several studies (Celik et al., 2016; Bayarcelik \& Findikli, 2016; Hussain \& Khan, 2018; Ekmekcioglu \& Aydogan, 2019; George \& Wallio, 2017) indicated that organizational justice could affect turnover intentions negatively. From those studies, the dimensions of organizational justice that mostly influence turnover intentions are distributive justice and procedural justice.

H1: There is a negative and significant relationship between Organizational Justice and Turnover Intentions

\section{Organizational Justice (OJ) and Job Satisfaction (JS)}

According to As'ad (1998), some factors can affect job satisfaction, such as social factors (related to coworker interactions and superior-subordinate interactions) and financial factors (related to employee security and welfare, especially from the financial side). Some influencing factors of job satisfaction are, distributive and interactional justice. Distributive justice is employees' perception of justice based on the outcomes they receive. Meanwhile, interactional justice is employees' perception of justice based on interactions they received and experienced (Niehoff \& Moorman, 1993; Colquit, 2001; Robbins \& Judge, 2105). Thus, organizational justice is assumed to be positively related to job satisfaction. That is, an increase in organizational justice will increase employees' job satisfaction. Several studies (Zainalipour et al., 2010; Sembiring et al., 2020; Nojani et al., 2012; Nadiri \& Tanova, 2010) supported this statement.

$\mathrm{H} 2$ : There is a positive and significant relationship between Organizational Justice and

Job Satisfaction

\section{Job Satisfaction (JS) and Turnover Intentions (TI)}

As mentioned before, several factors influence turnover intentions, such as low salary, inflexible working hours, and low career advancement opportunities. Besides those factors, another factor influencing turnover intentions is job satisfaction (Ghiselli et al., 2001). Job satisfaction involves dimensions of the job itself, salary, and promotion opportunities. If the organization fills the dimensions, employees will feel satisfied with their job (Luthans, 2006). Thus, job satisfaction can negatively influence employees' turnover intentions because the higher the level of employees' satisfaction is, the lower their turnover intentions be. Several studies (Nadiri \& Tanova, 2010; Nojani et al., 2012) have proven the negative relationship between JS and TI.

$\mathrm{H}_{3}$ : There is a negative and significant relationship between Job Satisfaction and Turnover Intentions

\section{The role of Job satisfaction as mediator}

The theories in the previous sections provide an overview that mentioned OJ, JS, and TI are interrelated. The transmission includes influencing factors of the three variables. The influencing factors of job satisfaction involve social and financial aspects related to distributive and interactional justice. Then, the influencing factors of turnover intention involving salary, career advancement opportunities, and inflexible working hours are part of job satisfaction related to the dimensions of salary, the job itself, and promotion opportunities. Based on the transmission, it can be assumed that JS can mediate OJ and TI. The transmission theory has been noted by past studies (Bayarcelik \& Findikli, 2016; Suifan et al., 2017; Zagladi et al., 2015), that found job satisfaction can mediate the relationship between organizational justice and turnover intentions.

$\mathrm{H}_{4}$ : Job Satisfaction mediate the relationship between Organizational Justice and Turnover Intentions

\section{Methods}

This study used a quantitative research design to examine samples, collect the data using research instruments, analyze data statistically, and test the determined hypotheses (Sugiyono, 2012). The number of employees in the Sumatera regional branch offices of PT. Tiga Serangkai Pustaka Mandiri is 101 employees by February 2021. This study took the entire employees, the population of the branch office employees, as the sample of the study. Moreover, for collecting data, it was done by distributing questionnaires with closed statements. Furthermore, the hypotheses were tested by using PLS-SEM method with SmartPLS 3.0 Software. Then, the operational definition of the variables in this study are as follows: 
Table 1. Operational Variable Definitions

\begin{tabular}{|c|c|c|c|c|}
\hline No. & Variable & $\begin{array}{l}\text { Operational } \\
\text { Definitions }\end{array}$ & Dimension & Indicator \\
\hline \multirow[t]{3}{*}{1.} & \multirow[t]{3}{*}{$\begin{array}{l}\text { Organizational } \\
\text { Justice } \\
\text { (independent } \\
\text { variable) }\end{array}$} & \multirow[t]{3}{*}{$\begin{array}{l}\text { Organizational justice } \\
\text { is employee's } \\
\text { perception of the } \\
\text { decision-making } \\
\text { process, rewards, and } \\
\text { interactions within the } \\
\text { organization } \\
\text { (Greenberg \& Baron, } \\
\text { 2008) }\end{array}$} & $\begin{array}{l}\text { Distributive } \\
\text { Justice }\end{array}$ & $\begin{array}{l}\text { 1. Compatibility of what the } \\
\text { company provides and what } \\
\text { employees do. } \\
\text { 2. Compatibility of comparable } \\
\text { results that all employees } \\
\text { received. } \\
\text { 3. Compatibility of equal } \\
\text { facilities that all employees } \\
\text { received. }\end{array}$ \\
\hline & & & $\begin{array}{l}\text { Procedural } \\
\text { Justice }\end{array}$ & $\begin{array}{l}\text { The company system is consistent, } \\
\text { impartial, and open. }\end{array}$ \\
\hline & & & $\begin{array}{l}\text { Interactional } \\
\text { Justice }\end{array}$ & $\begin{array}{l}\text { 1. Leaders are kind and respectful } \\
\text { to employees } \\
\text { 2. Communication between } \\
\text { leaders and employees is equal } \\
\text { 3. Leaders treat all employees } \\
\text { equally. }\end{array}$ \\
\hline 2. & $\begin{array}{l}\text { Turnover } \\
\text { Intentions } \\
\text { (dependent } \\
\text { variable) }\end{array}$ & $\begin{array}{l}\text { Turnover intentions } \\
\text { are employee } \\
\text { intentions to leave } \\
\text { their job or the } \\
\text { company to find } \\
\text { another job (Purani \& } \\
\text { Sahadev, 2008) }\end{array}$ & $\begin{array}{l}\text { Employee's } \\
\text { desire to leave an } \\
\text { organization }\end{array}$ & $\begin{array}{l}\text { 1. Actively looking for another job } \\
\text { 2. Thinking about going their } \\
\text { current job } \\
\text { 3. Possibility of looking for a new } \\
\text { job in the future }\end{array}$ \\
\hline \multirow[t]{5}{*}{3.} & \multirow{5}{*}{$\begin{array}{l}\text { Job Satisfaction } \\
\text { (mediation } \\
\text { variable) }\end{array}$} & \multirow{5}{*}{$\begin{array}{l}\text { Job satisfaction is the } \\
\text { level of employees' } \\
\text { positive perceptions } \\
\text { of their work. } \\
\text { (Robbins \& Judge, } \\
\text { 2015) }\end{array}$} & The Job & $\begin{array}{l}\text { 1. Interesting job } \\
\text { 2. Opportunities for learning }\end{array}$ \\
\hline & & & Salary & $\begin{array}{l}\text { 1. The compatibility of } \\
\text { compensation with what } \\
\text { employees give to the company } \\
\text { 2. Employees get bonuses or } \\
\text { incentives. }\end{array}$ \\
\hline & & & $\begin{array}{l}\text { Promotion } \\
\text { Opportunity }\end{array}$ & $\begin{array}{l}\text { 1. The company has a clear career } \\
\text { path } \\
\text { 2. The company provides } \\
\text { opportunities for career } \\
\text { development }\end{array}$ \\
\hline & & & Supervision & $\begin{array}{l}\text { Supervisors provide technical } \\
\text { support and feedback to } \\
\text { employees. }\end{array}$ \\
\hline & & & Coworkers & $\begin{array}{l}\text { Coworkers provide technical and } \\
\text { social support. }\end{array}$ \\
\hline
\end{tabular}

\section{Result and Discussions}

Outer Model Test Results

\section{Convergent Validity Test Results}

Convergent validity is the correlation between indicator scores and constructs scores. The following is the result of the correlation between the indicators and their constructs:

Table 2. Outer Loading Value

\begin{tabular}{|c|c|c|c|}
\hline Statement Items & Organizational Justice & Job Satisfaction & Turnover Intentions \\
\hline KK1 & & 0.572 & \\
\hline KK10 & & 0.730 & \\
\hline KK2 & & 0.698 & \\
\hline KK3 & & 0.832 & \\
\hline KK4 & & 0.793 & \\
\hline
\end{tabular}




\begin{tabular}{|c|c|c|c|}
\hline KK5 & & 0.847 & \\
\hline KK6 & & 0.702 & \\
\hline KK7 & & 0.813 & \\
\hline KK8 & & 0.713 & \\
\hline KK9 & & 0.442 & \\
\hline KO1 & 0.778 & & \\
\hline $\mathrm{KO} 2$ & 0.616 & & \\
\hline KO3 & 0.624 & & \\
\hline KO4 & 0.792 & & \\
\hline KO5 & 0.830 & & \\
\hline KO6 & 0.721 & & \\
\hline KO7 & 0.738 & & \\
\hline KO8 & 0.698 & & \\
\hline KO9 & 0.537 & & \\
\hline TI1 & & & 0.875 \\
\hline TI2 & & & 0.799 \\
\hline TI3 & & & 0.855 \\
\hline
\end{tabular}

Based on Table 2, the outer loading value for the statement items in the organizational justice variable has a value above 0.7 and some below 0.7 . The statement items for the organizational justice variable with a value above 0.7 are items with codes $\mathrm{KO} 1, \mathrm{KO} 4, \mathrm{KO} 5, \mathrm{KO} 6$, and $\mathrm{KO} 7$, while the statement items with codes $\mathrm{KO} 2, \mathrm{KO} 3, \mathrm{KO} 8$, and $\mathrm{KO} 9$ have a loading factor value of $<0.7$. Thus. It will be removed from the model. Then, the outer loading value for the statement items in the job satisfaction variable is above 0.7 , and some are below 0.7 . The statement items for the job satisfaction variable with a value above 0.7 are statement items with codes KK3, KK4, KK5, KK6, KK7, KK8, and KK10, while the value for statement items with codes $\mathrm{KK} 1, \mathrm{KK} 2$, and KK9 is below 0.7. Thus, the statement items coded KK1, KK2 and KK9 will be removed from the model. Furthermore, the outer loading value for the statement items in the turnover intentions variable is above 0.7 . Thus, all statement items in the turnover intentions variable have met convergent validity.

Table 3. Improvement Results of Outer Loading Value

\begin{tabular}{|c|c|c|c|}
\hline Statement Items & Organizational Justices & Job Satisfaction & Turnover Intentions \\
\hline KK10 & & 0.745 & \\
\hline KK3 & & 0.816 & \\
\hline KK4 & & 0.790 & \\
\hline KK5 & & 0.869 & \\
\hline KK6 & & 0.718 & \\
\hline KK7 & & 0.814 & \\
\hline KK8 & & 0.718 & \\
\hline KO1 & 0.750 & & \\
\hline $\mathrm{KO} 4$ & 0.851 & & \\
\hline KO5 & 0.880 & & \\
\hline KO6 & 0.778 & & \\
\hline KO7 & 0.734 & & \\
\hline TI1 & & & 0.873 \\
\hline TI2 & & & 0.800 \\
\hline TI3 & & & 0.856 \\
\hline
\end{tabular}

Table 3 shows that the outer loading value of all statement items for all variables is greater than 0.7 . Thus, the statement items for all variables are valid. 
Table 4. Average Variance Extracted (AVE) Value

\begin{tabular}{lc}
\hline \multicolumn{1}{c}{ Variable } & Average Variance Extracted (AVE) \\
\hline Organizational Justice & 0.641 \\
\hline Job Satisfaction & 0.613 \\
\hline Turnover Intentions & 0.712 \\
\hline
\end{tabular}

Table 4 shows that the AVE value for all variables is more significant than 0.5. Based on the Outer Loading and AVE values, this research data has met the requirements of Convergent Validity.

Discriminant Validity Test Results

The discriminant validity test measured the cross-loading values. The value of cross loading in the model is as follows:

Table 5. Cross Loading Value

\begin{tabular}{lccc}
\hline \multicolumn{1}{c}{ Statement Items } & Orgnanizational Justice & Job Satisfaction & Turnover Intentions \\
\hline KK10 & 0.458 & 0.745 & -0.645 \\
\hline KK3 & 0.515 & 0.816 & -0.382 \\
\hline KK4 & 0.533 & 0.790 & -0.394 \\
\hline KK5 & 0.572 & 0.869 & -0.580 \\
\hline KK6 & 0.417 & 0.718 & -0.488 \\
\hline KK7 & 0.481 & 0.814 & -0.483 \\
\hline KK8 & 0.459 & 0.718 & -0.409 \\
\hline KO1 & 0.750 & 0.393 & -0.490 \\
\hline KO4 & 0.851 & 0.442 & -0.449 \\
\hline KO6 & 0.880 & 0.481 & -0.574 \\
\hline KO7 & 0.778 & 0.530 & -0.400 \\
\hline TI1 & 0.734 & 0.641 & -0.399 \\
\hline TI2 & -0.442 & -0.524 & 0.873 \\
\hline TI3 & -0.367 & -0.421 & 0.800 \\
\hline
\end{tabular}

Table 5 shows the cross-loading value of all indicators exceeding the value of 0.7 . Hence, the statement items for each variable have met discriminant validity.

\section{Reliability Test Results}

The composite reliability value of each variable is as follows

Table 6. Composite Reliability Value

\begin{tabular}{lcc}
\hline \multicolumn{1}{c}{ Variable } & Cronbach's Alpha & Composite Reliability \\
\hline Organizational Justice & 0.858 & 0.899 \\
\hline Job Satisfaction & 0.894 & 0.917 \\
\hline Turnover Intentions & 0.801 & 0.881 \\
\hline
\end{tabular}

Based on Table 6, the composite reliability value and Cronbach's alpha value for each variable are greater than 0.7 . It can be concluded that variable in this study have met the reliability.

\section{Inner Model Test Results}

The evaluation of the inner model or structural model test measure the direct and indirect effects between variables. The next table presented the R-Square values. 
Table 7. R-Squared Value

\begin{tabular}{lc}
\hline & R Square \\
\hline Job Satisfaction & 0.395 \\
\hline Turnover Intentions & 0.450 \\
\hline
\end{tabular}

Table 7 showed that the R-squared value of the job satisfaction variable is 0.395 . It indicated that the organizational justice variable can affect the job satisfaction variable by $39.5 \%$. On the other hand, the remaining $60.5 \%$ can be defined by other variables outside the model. Then, the R-Squared value of the turnover intention's variable is 0.450 . It means that organizational justice and job satisfaction can affect the turnover intentions variable by $45 \%$, while other variables outside the model indicate the remaining $55 \%$.

\section{The goodness of Fit Rating}

Based on the calculation results, the Q2 value of 0.67 means that the diversity of the data can be explained by the structural model developed in this study, which is 67\%. This result indicates that the structural model in this study has good goodness of fit.

Further evaluation of the inner model was done by looking at the path diagram showing the significance of the independent variable to the dependent variable. Figure 1 shows a path diagram of the model.

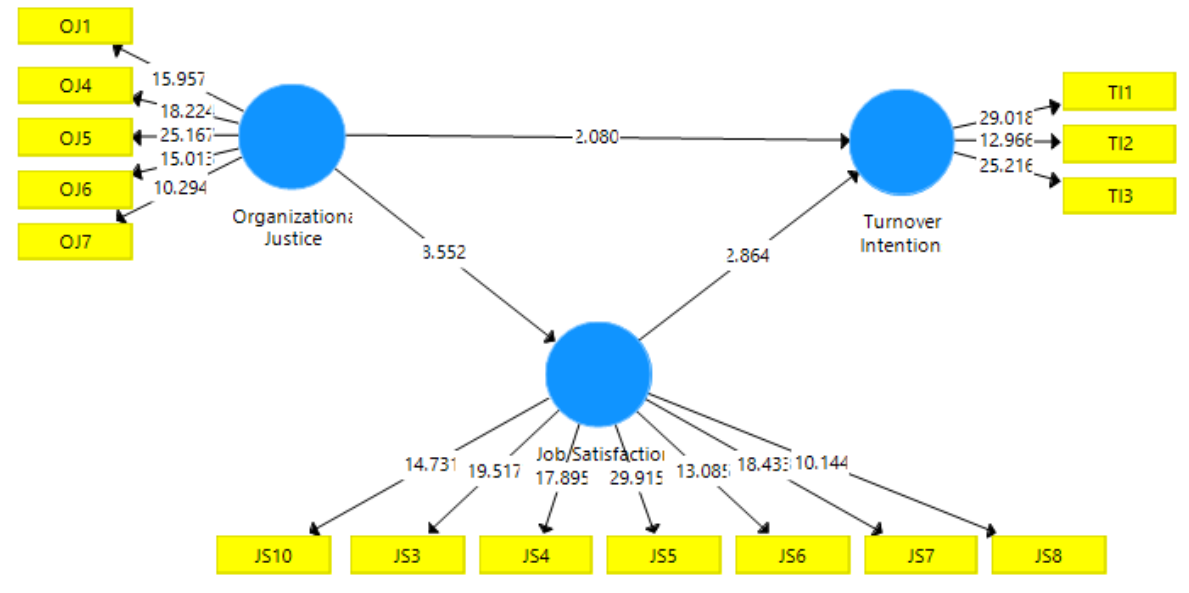

Figure 1. Path Diagram

Following table are the results of the hypotheses test:

Table 8. Hypotheses Test Results by PLS-SEM

\begin{tabular}{lccccc}
\hline & $\begin{array}{c}\text { Original } \\
\text { Sample } \\
(\mathrm{O})\end{array}$ & $\begin{array}{c}\text { Sample } \\
\text { Mean } \\
(\mathrm{M})\end{array}$ & $\begin{array}{c}\text { Standard } \\
\text { Deviation } \\
(\text { STDEV })\end{array}$ & $\begin{array}{c}\text { T Statistics } \\
(\mid \mathrm{O} / \text { STDEV })\end{array}$ & $\begin{array}{c}\mathrm{P} \\
\text { Values }\end{array}$ \\
\hline $\begin{array}{l}\text { Organizational justice -> } \\
\text { Job Satisfaction }\end{array}$ & 0.629 & 0.631 & 0.071 & 8.860 & 0.000 \\
\hline $\begin{array}{l}\text { Organizational Justice -> } \\
\text { Turnover Intentions }\end{array}$ & -0.307 & -0.286 & 0.142 & 2.162 & 0.031 \\
\hline $\begin{array}{l}\text { Job Satisfaction -> } \\
\text { Turnover Intentions }\end{array}$ & -0.434 & -0.459 & 0.148 & 2.937 & 0.003 \\
\hline $\begin{array}{l}\text { Organizational Justice -> } \\
\text { Job Satisfaction -> } \\
\text { Turnover Intentions }\end{array}$ & -0.273 & -0.290 & 0.102 & 2.682 & 0.008 \\
\hline
\end{tabular}

Table 8 shows the t-statistical values and t-table values that later will be compared. First, the variable of organizational justice on turnover intentions has a negative coefficient sign. The t-statistic value is $2.162>$ the $\mathrm{t}$-table value is 1.98373 , and the $\mathrm{P}$-value is $0.031<$ alpha $5 \%$. Thus, $\mathrm{H}_{1}$ is accepted. It can be concluded that OJ has a negative and significant impact on TI.

Second, organizational justice on job satisfaction has a positive coefficient sign. The t-statistic value is $8.860>$ the $\mathrm{t}$-table value is 1.98373 , and the $\mathrm{P}$-value is $0.000<$ alpha $5 \%$. Thus, $\mathrm{H}_{2}$ is accepted. The results showed that OJ has a positive and significant impact on JS.

Third, job satisfaction on turnover intentions has a negative coefficient sign. The t-statistic value is 2.937 $>$ the t-table value is 1.98373 , and the $\mathrm{P}$-value is $0.003<$ alpha $5 \%$. Thus, $\mathrm{H}_{3}$ is accepted. It implies there is a negative and significant relationship between JS and TI. 
Fourth, organizational justice on turnover intentions through job satisfaction has a negative coefficient sign. The t-statistic value is $2.682>$ the t-table value is 1.98373 , and the $\mathrm{P}$-value is $0.008<$ alpha $5 \%$. Thus, $\mathrm{H}_{4}$ is also accepted. The data showed that OJ has a negative and significant impact on TI through JS.

\section{The Direct effect Organizational Justice on Turnover Intentions at PT. Tiga Serangkai Pustaka Mandiri in Sumatra region}

Based on the hypothesis test, organizational justice negatively and significantly affects turnover intentions, indicated by a negative coefficient sign. The t-statistic value is $2.080>1.98373$, and the P-value is $0.038<$ alpha $5 \%$. Then, the path coefficient value of -0.307 means an increasing in organizational justice, will affect an decreasing the turnover intentions by 0.307 . The result illustrated that this study's proposed hypothesis, based on the theories and previous studies, has been proven to be true. An individual or employee will evaluate whether the results of what they get from an organization follow the effort they put into the organization (Niehoff \& Moorman, 1993; Colquit, 2001; Robbins \& Judge, 2015). An employee who gets a high sense of organizational justice will reduce turnover intentions. It is in line with several studies (Celi et al., 2016; Bayarcelik \& Findikli, 2016; Hussain \& Khan, 2018; Ekmekcioglu \& Aydogan, 2019; George \& Wallio, 2017), which showed a negative effect of organizational justice on turnover intentions. This result suggested PT. Tiga Serangkai Pustaka Mandiri in Sumatera Region to improve the organizational justice for reducing the turnover intentions of its employees.

\section{The Direct effect Organizational Justice on Job Satisfaction at PT. Tiga Serangkai Pustaka Mandiri in Sumatera Region}

Based on the hypothesis test, a positive coefficient sign indicates that organizational justice positively and significantly affects job satisfaction. The t-statistic value is $8.552>1.98373$, and the P-value is $0.000<$ alpha $5 \%$. Then, the path coefficient value of 0.629 means that an increase in organizational justice will increase job satisfaction by 0.629 . The result indicated that the proposed hypothesis had been proven to be true. Distributive justice is based on individual or employees' results, and interactional justice is justice based on aspects of interactions received and experienced by individuals or employees (Niehoff \& Moorman, 1993; Colquit, 2001; Robbins \& Judge, 2015). If employees perceived organizational justice is fair, their job satisfaction will increase. It is supported by some studies (Zainalipour et al., 2010; Sembiring et al., 2020; Nojani et al., 2012; Nadiri \& Tanova, 2010), which showed a positive effect of organizational justice on job satisfaction. It is suggested that the company always improve organizational justice to increase the employees' job satisfaction.

\section{The Dierct Effect of Job Satisfaction on Turnover Intentions at PT. Tiga Serangkai Pustaka Mandiri in Sumatera Region}

Based on the hypothesis test, job satisfaction can negatively and significantly affect turnover intentions which are indicated by a negative coefficient sign, the t-statistic value is $2.864>1.98373$, and the P-value is $0.004<$ alpha $5 \%$. Then, the path coefficient value of -0.434 means that inflation in job satisfaction will decrease the turnover intentions of 0.434 . The result illustrated that the proposed hypothesis had been proven to be true. If the organization could offer dimensions of job satisfaction, employees will gain job satisfaction, reducing turnover intentions in an organization (Luthans, 2006). Thus, job satisfaction can negatively influence employee turnover intentions; if job satisfaction increases, turnover intentions will decrease. It is in line with several studies (Nadiri \& Tanova, 2010; Nojani et al., 2012), which showed a negative and significant relationship between job satisfaction and turnover intentions. Therefore, it is recommended for PT. Tiga Serangkai Pustaka Mandiri Sumatera Region to maintain and improve the employee's job satisfaction to cut down the turnover intentions of its employees.

\section{The Indirect Effect of Organizational Justice on Turnover Intentions}

The hypothesis test showed that organizational justice has a negative and significant effect on turnover intentions through job satisfaction. A negative coefficient sign indicates it, the t-statistic value is $2.525>$ 1.98373, and the P-Value is 0.012 < alpha 5\%. Then, the path coefficient value of -0.273 shows a negative influence between organizational justice and turnover intentions through job satisfaction, which is -0.273 .

The result indicated that the proposed hypothesis had been proven to be true. Distributive justice is employees' perception of the justice they got, and interactional justice is employees' perceptions based on their interactions or experiences (Niehoff \& Moorman, 1993; Colquit, 2001; Robbins \& Judge, 2015). If employees get organizational justice, their job satisfaction will increase, and later can reduce the turnover intentions in an organization (Luthans, 2006). It was supported by the previous studies (Bayarcelik \& Findikli, 2016; Suifan et al., 2017; Zagladi et al., 2015) that found job satisfaction mediates between organizational justice and turnover intentions. Thus, the company must improve organizational justice and job satisfaction first to reduce turnover intentions of PT. Tiga Serangkai Pustaka Mandiri. 


\section{Conclusions and Sugggestions}

The results of this study have drawn into some conclusion, as follow: First, organizational justice relate to turnover intentions significant negatively. The increase of organizational justice will reduce turnover intentions at the company. Second, organizational justice relate to job satisfaction significant positvely. Thus, the increase of organizational justice will also increase job satisfaction. Third, job satisfaction relate to turnover intentions significant positively. Thus, the rise of job satisfaction will lessen turnover intentions. Finally, fourth, Organizational justice negatively affects turnover intentions through job satisfaction. That is, job satisfaction act as mediator variable on the relationship between organizational justice and turnover intentions.

To avoid Employee Turnover Intentions, PT. The Three Series of Independent Libraries for the Sumatra Region can do the following: (1) Creating a reward system in the form of (salary and incentives) that is applied to all employees, the aim is that employees get organizational justice which can then reduce turnover intentions. (2) Creating a clear and measurable career path system for employees, the goal is for employees to get job satisfaction which can then reduce turnover intentions. For academician, it was suggested to examine another factors outside this research model in decreasing turnover intention.

\section{References}

Arab, H. R., \& Atan, T. (2018). Organizational Justice and Work Outcomes in The Kurdistan Region of Iraq. Management Decision. 0025-1747.

As’ad, M. (1998). Psikologi Industri: Seri Ilmu Sumber Daya Manusia. Yogyakarta: Liberty.

Bayarcelik,, E., \& Findikli, M. (2016). The Mediating Effect of Job Satisfaction On The Relation Between Organizational Justice Perception And Intention To Leave. Procedia - Social and Behavioral Sciences, 235, 403-411.

Celik, D. A., \& al. (2016). The Moderating Role of Self Efficacy on the Perceptions of Justice and Turnover Intentions. Procedia - Social and Behavioral Sciences, 235, 392-402.

Colquitt, J. (2001). On the Dimensionality of Organizational Justice: A Construct Validation of A Measure. Journal of Applied Psychology, 86 (3), 386-400.

Dessler, G. (2011). Manajemen sumber daya Manusia. Jakarta: Penerbit Indeks.

Ekmekcioglu, E., \& Aydogan, E. (2019). A Moderated Mediation Model of The Relationship between Organizational Justice and Turnover Intention. International Journal of Organizational Analysis: 19348835 .

George, J., \& Wallio, S. (2017). Organizational justice and Millennial Turnover in Public Accounting. Employee Relations, Vol. 39 Iss 1, 112-126.

Ghiselli, R. (2001). Job Satisfaction, Life Satisfaction, and Turnover Intent. Cornell Hotel \& Restaurant Administration Quarterly, 42 (2), 28-37.

Greenberg, J., \& Robert, A. (2008). Behavior in Organization, 8th ed. New Jersey: Prentice Hall.

Hussain, M., \& Khan, M. (2018). Organizational Justice and Turnover Intentions: Probing The Pakistani Print Media Sector. Evidence-based HRM: a Global Forum for Empirical Scholarship: 2049-3983.

Luthans, F. (2006). Perilaku Organisasi, Edisi Sepuluh. Yogyakarta: PT. Andi.

Mobley, W. (1977). Intermediate Linkages in the Relationship Between Job Satisfaction and Employee Turnover. Journal of Applied Psychology, 62 (2), 237-240.

Nadiri, H., \& Tanova, C. (2010). An Investigation of The Role of Justice in Turnover Intentions, Job Satisfaction, and Organizational Citizenship Behavior in Hospitality Industry. International Journal of Hospitality Management, 29(1), 33-41.

Niehoff, B., \& Moorman, R. (1993). Justice as A mediator of The Relationship between Methods of Monitoring and Organizational Citizenship Behavior. Academy of Management Journal, 36, 527-556.

Nojani, M. I., \& al. (2012). The Study on Relationship between Organizational Justice and Job Satisfaction in Teachers Working in General, Special and Gifted Education Systems. Procedia - Social and Behavioral Sciences, 46, $2900-2905$.

Robbins, S., \& Judge, T. (2015). Perilaku Organisasi. Jakarta: Salemba Empat.

Sanderson, P. (2003). The Relationship between Empowerment and Turnover Intentions in A Structured Environment: An Assessment of The Navy's Medical Service Corps. Ph.D. dissertation, Regent University, United States - Virginia.

Sembiring, N., \& al. (2020). The Effects of Emotional Intelligence and Organizational Justice on Job Satisfaction, Caring Climate, and Criminal Investigation Officers' Performance. International Journal of Organizational Analysis: 1934-8835.

Shields, M., \& Ward, M. (2001). Improving Nurse Retention in The National Health Service in England: The impact of Job Satisfaction on Intentions to Quit. Journal of Health Economics Elsevier, 20(5), 677-701.

Suifan, T. S., \& al. (2017). Does Organizational Justice Affect Turnover Intention in A Developing Country? The Mediating Role of Job Satisfaction and Organizational Commitment. Journal of Management Development, 36 (9), 1137-1148. 
Zagladi, A. N., \& al. (2015). The Role of Job Satisfaction and Power Distance in Determining The Influence of Organizational Justice toward The Turnover Intentions. Procedia - Social and Behavioral Sciences, 211, 42-48.

Zainalipour, H., \& al. (2010). A Study of Relationship between Organizational Justice and Job Satisfaction among Teachers in Bandar Abbas Middle School. Procedia Social and Behavioral Sciences, 5, 19861990. 